\title{
Factors Identification for Human Development Index
}

\author{
Anam Javaid ${ }^{1}$ and Atif Akbar ${ }^{2}$ \\ ${ }^{1}$ Department of Mathematical sciences, University Sains Malaysia \\ ${ }^{2}$ Department of Statistics, Bahauddin Zakariya UniversityMultan, Pakistan \\ Coresponding Auhors: anamjavaid7860@yahoo.com
}

\begin{abstract}
Human development index matters a lot for the economic condition of a country. It can be calculated with the help of the education index, health index, and GDP. So, by looking only at the value of the human development index (HDI), the economy of the country can be judged. The contribution of this research project is the identification of factors related to human development. The factors include the availability of the basic necessities, facilities related to education, health, and income. For this purpose, different important factors have been observed for the Multan district by taking MICS (2007-2008) survey data. Logistic regression is applied for the purpose of analysis. Significant factors are noted in each regression analysis based on the dependent factor.
\end{abstract}

Key words:Human developmentindex, Economic condition, Education health.

\section{Introduction}

Human development index able us to measure the development level of a country. The standard of living and the quality of life can be judge by it. Many researchers are working for the human development index (HDI) so that the quality of life for that country can be analyzed as Frey and Schneider (1979) analyzed the policy instrument that government used for making policy and they also indicated that which type of policy proposal accepted by the government. Akbar and Altaf (1995) analyzed the effect of different utility variables like electricity, gas, and water in the rent of the dwelling unit in the Karachi squatter arrangement. Peykarjou et al. (2011) studied the relationship between economic growth and health in Organization Islamic Conference members 
by using data from 2001-2009. Ahmad and Riaz (2012) estimated poverty in Pakistan after using data from 1974 -2009. Ajmair and Akhtar (2012) examined factors that effects on household consumption by using data of district Bhimber, AJK (Azad Jammu Kashmir). This present study is an attempt to finding determents of different variables likewise used in previous studies. This study is based on MICS (Multiple Indicator Cluster Survey) data of 2007-2008 for the Multan district.

One of the research was conducted by Luby and Rahbar (1999) as they examined the health facilities available to under five-year children. Later on, Glick and Sahn (2000) examined the multiple schooling indicators. Heltberg (2004) found the factors related to the fuel in the household. Javaid, A et al. (2018) reviewed the factors related to the human development index.

Many reserachers used different statistical techniques for finding the factors related to the human development index. This research project identified the significant factors related to HDI.

\section{Methodology}

\section{Logistic Regression analysis}

Rencher and Schaalje (2007) explained that in some regression situations, the response variable $y$ has only two possible outcomes, for example, high blood pressure or low blood pressure, developing cancer of the esophagus or not developing it, whether a crime will be solved or not solved, and whether a bee specimen is a "killer" (Africanized) bee or a domestic honey bee. In such cases, the outcome y can be coded as 0 or 1 and we wish to predict the outcome (or the probability of the outcome) on the basis of one or more $x$ 's.To illustrate a linear model in which $y$ is binary, consider the model with one $x$ :

$$
y_{i}=\beta_{0}+\beta_{1} x_{1}+\epsilon_{i} ; \quad y_{i}=0,1,2, \ldots, n .
$$

Since $y_{i}$ is 0 or 1 , the mean $E\left(y_{i}\right)$ for each $x_{i}$ becomes the proportion of observations at $x_{i}$ for which $y_{i}=1$. This can be expressed as

$$
\begin{aligned}
& E\left(y_{i}\right) \quad=\quad P\left(y_{i}=1\right)=p_{i}, \\
& 1-E\left(y_{i}\right)=P\left(y_{i}=0\right)=1-p_{i} \text {. }
\end{aligned}
$$


The distribution $P\left(y_{i}=0\right)=1-p_{i}$ and $P\left(y_{i}=1\right)=p_{i}$ in (3) is known as the Bernoulli distribution. By (1) and (2), we have

$$
E\left(y_{i}\right)=p_{i}=\beta_{0}+\beta_{1} x_{i} .
$$

For the variance of $y_{i}$, we obtain

$$
\begin{aligned}
& \operatorname{Var}\left(y_{i}\right) \quad=\quad E\left[y_{i}-E\left(y_{i}\right)\right]^{2} \\
& =\quad p_{i}\left(1-p_{i}\right)(4)
\end{aligned}
$$

By (3) and (4), we obtain

$$
\operatorname{Var}\left(y_{i}\right)=\left(\beta_{0}+\beta_{1} x_{i}\right)\left(1-\beta_{0}-\beta_{1} x_{i}\right),
$$

and the variance of each $y_{i}$ depends on the value of $x_{i}$. Thus the fundamental assumption of constant variance is violated, and the usual least-squares estimators $\hat{\beta}_{0}$ and $\hat{\beta}_{1}$ computed. To obtain optimal estimators of $b_{0}$ and $b_{1}$, we could use generalized least squares estimators

$$
\hat{\beta}=\left(X^{\prime} V^{-1} X\right)^{-1} X V^{1} y
$$

But there is an additional challenge in fitting the linear model(4). Since $E\left(y_{i}\right)=p_{i}$ is a probability, it is limited by $0 \leq p_{i} \leq 1$. If we fit (4) by generalized least squares to obtain

$$
\hat{p}_{i}=\hat{\beta}_{0}+\hat{\beta}_{1} \mathrm{x}_{\mathrm{i}},
$$

then $\hat{p}_{i}$ may be less than 0 or greater than 1 for some values of $x_{i}$. A model for $E\left(y_{i}\right)$ that is bounded between 0 and 1 and reaches 0 and 1 asymptotically (instead of linearly) would be more suitable. A popular choice is the logistic regression model.

$$
p_{i}=\mathrm{E}(y i)=\frac{e^{\beta 0+\beta_{1 X 1}}}{1+e^{\beta 0+\beta_{1 X 1}}}=\frac{1}{1+e^{-\beta 0-\beta 1 X 1}}
$$

The model in (5) can be linearized by the simple transformation

$$
\ln (p i /(1-p i))=\beta_{0}+\beta_{1} \mathrm{x}_{1}
$$

Sometimes called the logit transformation.

The parameters $\beta_{0}$ and $\beta_{1}$ in (5) and (6) are typically estimated by the method of maximum likelihood. For a random sample $y_{1}, y_{2}, \ldots, y_{n}$ from the Bernoulli distribution with

$$
\begin{aligned}
& P\left(y_{i}=0\right)=1-p_{i} \text { and } P\left(y_{i}=1\right)=p_{i} \text {, the likelihood function becomes } \\
& L\left(\beta_{0}, \beta_{1}\right)=f\left(y_{1}, y_{2}, \ldots, y_{n}, \beta_{0}, \beta_{1}\right)=\prod_{i=1}^{n} f\left(y_{i} ; \beta_{0}, \beta_{1}\right)=\prod_{i=1}^{n} p_{i}^{y_{i}}\left(1-p_{i}\right)^{1-y_{i}(7)}
\end{aligned}
$$

Taking the logarithm of both sides of (7) and using (6), we obtain 


$$
\ln L\left(\beta_{0}, \beta_{1}\right)=\sum_{i=1}^{n} y_{i}\left(\beta_{0}+\beta_{1} x_{1}\right)-\sum_{i=1}^{n} \ln \left(1+e^{\beta 0+\beta 1 x 1}\right)
$$

Differentiating (8) with respect to $\beta_{0}$ and $\beta_{l}$ and setting the results equal to zero gives

$\sum_{i=1}^{n} y_{i}=\sum_{i=1}^{n} \frac{1}{1+e^{-\beta_{0}-\beta_{1} x_{1}}}$

$\sum_{i=1}^{n} x_{i} y_{i}=\sum_{i=1}^{n} \frac{x_{i}}{1+e^{-\beta_{0}-\beta_{1} x_{1}}}$

These equations can be solved iteratively for $\hat{\beta}_{0}$ and $\hat{\beta}_{1}$.

\section{Results and Discussion}

Data used in analysis was taken from MICS(2007-2008) with 51 variablescontaining 2892 observations. The results are analysed using the different dependent factors of HDI with the remaining independent factors. The coding are observed as for the factors related to HDI. The codings are observed in Table 1.

Table 1:Variable names with their Notations

\begin{tabular}{|c|c|c|c|c|c|}
\hline S.No. & Variable Name & Notations & S.No. & Variable Name & Notations \\
\hline 1 & Gender & A1 & 27 & Bicycle & F20 \\
\hline 2 & Type of dwelling & A2 & 28 & Motorcycle or scooter & F21 \\
\hline 3 & House Ownership & $\mathrm{A} 3$ & 29 & Car or truck & F22 \\
\hline 4 & Gas & $\mathrm{F} 2$ & 30 & Animal-driven cart & F23 \\
\hline 5 & Main material of roof & A5 & 31 & House area (Marla) & $\mathrm{C} 1$ \\
\hline 6 & Mai material of wall & A6 & 32 & House value (RS.) & $\mathrm{C} 2$ \\
\hline 7 & Television & F4 & 33 & Own agriculture land & $\mathrm{C} 3$ \\
\hline 8 & Electricity & F1 & 34 & Own livestock? & $\mathrm{C} 4$ \\
\hline 9 & $\begin{array}{l}\text { Number of rooms for } \\
\text { sleeping }\end{array}$ & A4 & 35 & $\begin{array}{l}\text { Received any pension } \\
\text { last year? }\end{array}$ & $\mathrm{C} 5$ \\
\hline 10 & Radio/Tape recorder & F3 & 36 & Cable TV & F5 \\
\hline 11 & $\begin{array}{l}\text { Purchase goods from } \\
\text { government utility } \\
\text { stores }\end{array}$ & C6 & 37 & $\begin{array}{l}\text { Consider government } \\
\text { utility stores as } \\
\text { beneficial to a common } \\
\text { man }\end{array}$ & $\mathrm{C} 7$ \\
\hline
\end{tabular}




\begin{tabular}{|c|c|c|c|c|c|}
\hline 12 & $\begin{array}{l}\text { Type of fuel used for } \\
\text { cooking }\end{array}$ & A7 & 38 & $\begin{array}{l}\text { Primary-Government. } \\
\text { Boys }\end{array}$ & E1 \\
\hline 13 & $\begin{array}{l}\text { Middle-Government. } \\
\text { Boys }\end{array}$ & E5 & 39 & $\begin{array}{l}\text { Primary-Government. } \\
\text { Girls }\end{array}$ & E2 \\
\hline 14 & Mobile Phone & F7 & 40 & Primary-Private .Boys & E3 \\
\hline 15 & Computer & F8 & 41 & Primary-Private. Girls & E4 \\
\hline 16 & Internet Connection & F9 & 42 & Telephone & F6 \\
\hline 17 & $\begin{array}{l}\text { Secondary- } \\
\text { Government. Boys }\end{array}$ & E9 & 43 & $\begin{array}{l}\text { Middle-Government. } \\
\text { Girls }\end{array}$ & E6 \\
\hline 18 & Air- Conditioner & F11 & 44 & Middle-Private. Boys & E7 \\
\hline 19 & $\begin{array}{l}\text { Washing } \\
\text { Machine/Dryer }\end{array}$ & F12 & 45 & Middle-Private. Girls & E8 \\
\hline 20 & Air cooler or fan & F13 & 46 & Refrigerator/Freezer & F10 \\
\hline 21 & $\begin{array}{l}\text { Cooking } \\
\text { range/Microwave }\end{array}$ & F14 & 47 & $\begin{array}{l}\text { Secondary-Government. } \\
\text { Girls }\end{array}$ & E10 \\
\hline 22 & $\begin{array}{l}\text { Secondary-Private. } \\
\text { Girls }\end{array}$ & E12 & 48 & Secondary-Private. Boys & E11 \\
\hline 23 & Iron & F16 & 49 & Stitching Machine & F15 \\
\hline 24 & $\begin{array}{l}\text { Distance to nearest } \\
\text { health facility (in } \\
\text { minutes) }\end{array}$ & $\mathrm{H} 2$ & 50 & $\begin{array}{l}\text { Type of nearest health } \\
\text { facility (government. or } \\
\text { Private) }\end{array}$ & H1 \\
\hline 25 & $\begin{array}{lll}\text { Donkey } & \text { Pump } & \text { or } \\
\text { turbine } & & \\
\end{array}$ & F18 & 51 & Water Filter & F17 \\
\hline 26 & Watch & F19 & & & \\
\hline
\end{tabular}

In this research, the factors related to education are kept as the dependent factors. Using the logistic regression analysis. Results are noted in terms of the significant factors only.

$$
\begin{aligned}
& \ln \left(\frac{E 1}{1-E 1}\right)=0.8808 E_{2}-0.2651 E_{6}-0.4532 E_{9}-0.3653 E_{11}+0.4085 E_{12} \\
& \ln \left(\frac{E 2}{1-E 2}\right)=-1.1912 A_{1}-1.9286 E_{1}-0.4685 E_{5}-0.7496 E_{7}-0.8257 E_{10}-1.2034 E_{12}
\end{aligned}
$$




$$
\begin{aligned}
& \ln \left(\frac{E 3}{1-E 3}\right)=-0.6580 E_{4} \\
& \ln \left(\frac{E 4}{1-E 4}\right)=-0.6501 E_{3} \\
& \ln \left(\frac{E 5}{1-E 5}\right)=-0.2408 E_{2}-1.2849 E_{6}-0.3878 E_{7}+0.5595 E_{8}-1.2964 E_{9}+0.8859 E_{10}+0.6695 E_{11}- \\
& 0.7418 E_{12} \\
& \ln \left(\frac{E 6}{1-E 6}\right)=-0.4779 E_{1}+0.3348 E_{2}-1.2909 E_{5}+1.3245 E_{9}-1.5580 E_{10}+0.2520 E_{12}-0.2691 H_{1} \\
& +0.2106 H_{2} \\
& \ln \left(\frac{E 7}{1-E 7}\right)=-0.6394 E_{8}+0.2956 E_{11}+0.2936 E_{12} \\
& \ln \left(\frac{E 8}{1-E 8}\right)=-0.6389 E_{7}-0.2000 E_{9}+0.1814 E_{10}+0.2691 E_{11}-0.2738 E_{12} \\
& \ln \left(\frac{E 9}{1-E 9}\right)=0.4219 F_{2}-0.3705 E_{1}+0.1807 E_{2}-0.6265 E_{5}+0.4315 E_{6}+0.6455 E_{7}-0.6837 E_{8}- \\
& 2.0560 E_{10} \\
& \ln \left(\frac{E 10}{1-E 10}\right)=\quad-0.1555 E_{2}+0.2378 E_{5}-0.4847 E_{6}-0.9142 E_{7}+0.9218 E_{8}+1.9146 E_{9} \\
& \ln \left(\frac{E 11}{1-E 11}\right)=-0.5612 E_{7}+0.5416 E_{8}-0.5947 E_{12} \\
& \ln \left(\frac{E 12}{1-E 12}\right)=\quad-0.2158 F_{2}+0.1241 E_{1}-0.1419 E_{2}+0.4999 E_{7}-0.5934 E_{11}
\end{aligned}
$$

By observing the different education factors, it is observed that for the education analysis, the average distance of school, gender, family structure, biological child, number of sisters in a family, number of brother in a family, occupation father, education father, education mother, house wealth, rural area, average distance of school, pupil child ratio, pupil teacher's ratio, \%age of men with a white collar job, $\%$ age of women with a white collar job, district development index, national GDP per capita, distance to nearest health facility, consider government utility store as beneficial to a common man, telephone, own agriculture land, animal driven cart and air conditioner are main significant factors for education. i.e. these all above variables have main effect on education.

For the health facilities, logistic regression is analysed using the health factors as dependent variable. The results are noted.

$$
\ln \left(\frac{H 1}{1-H 1}\right)=-4.6837 H_{2} \quad \ln \left(\frac{H 2}{1-H 2}\right)=-1.6511 F_{18}-7.6416 H_{1}
$$


In analysis for health facility,the important significant factors are distance to nearest health facility in minutes, education, age cohort, income, and respiratory problem.

For the house ownership, significant factor is identified using the logistic regression analysis.

$\ln \left(\frac{A 3}{1-A 3}\right)=-1.4080 A_{2}$

For house ownership, significant variables were type of dwelling with solid cement, dwelling with wall finish, index of quality of structure, number of floors, dwelling in neighborhoods, utility variables, wall, rooms and secondary government boys are main factors. i.e. for house ownership all above variables are important.

\section{Conclusion}

From the above result, important factors for different educational, health, and for other used dependent variable can be seen so its mean the above significant factors plays an important role in development of that dependent factor. The government policies can also be made for increment of HDI by focusing on these kind of factors. For the future work, multivariate analysis can be done for this kind of dataset.

\section{Acknowledgments}

The author would like to thank the Dr.AtifAkbar for the support and guidance in this research project.

\section{Acknowledgments}

The authors would like to thank the Editor for their guidline.

\section{References}

Ahmad, K. and Riaz, A. (2012). An Econometric Model of Poverty in Pakistan: ADRL Approach to Co-integration. Asian Journal of Business and Management sciences; $1(3), 75-84$.

Ajmair, M. and Akhtar, M. (2012).Household Consumption in Pakistan (A Case Study of District Bhimber, AJK).European Journal of Scientific Research. ISSN 1450-216X Vol.75 No.3, 448-457. 
Akbar, M. and Altaf, A. (1995). A Rent Hedonic Model of the low Income Housing Market in Karachi. Pakistan Economic and Social Review; 33(1/2 ), 79-90.

Frey, B.S. and Schneider, F. (1979).An Econometric Model with an Endogenous Government Sector.Springer 34, 29-43.

Glick, P., and Sahn, D. (2000). Gender and education impacts on Employment and Earnings in a Developing Country: the Case of Guinea. Economic Development and Cultural Change; 45(4), 793-823.

Heltberg, R. (2004). Fuel switching: Evidence from Eight Developing Countries. Energy Economics; 26, 869-887.

Javaid, A., Akbar, A., \& Nawaz, S. (2018). A Review on Human Development Index. Pakistan Journal of Humanities and Social Sciences, 6(3), 357-369.

Noorali, R. Luby, S. and Rahbar, M. H. (1999). Does Use of a Government Service Depend on Distance from the Health Facility?.Health Policy and Planning; 14(2), 191-197

Peykarjou.Gollu, R. B. and Gashti, H.P. (2011) Studying the Relationship Between Health and Economic Growth in OICMember states. 3(8), 1-14.

Rencher, A. C., \&Schaalje, G. B. (2007). Linear models in statistics. John Wiley \& Sons. 